\title{
円筒の弾塑性純曲げ崩壊に関する研究*
}

\author{
陳 玳 街*1, 増田健 一*2, 尾崎伸 吾*3
}

\section{Study on Elastoplastic Pure Bending Collapse of Cylindrical Tubes}

\author{
Dai-Heng CHEN*4, Kenichi MASUDA and Shingo OZAKI \\ ${ }^{* 4}$ Department of Mechanical Engineering, Tokyo University of Science, \\ 1-3 Kagurazaka, Shinjuku-ku, Tokyo, 162-8601 Japan
}

\begin{abstract}
In this paper, the elastoplastic bending collapse of cylindrical tube subjected to statically pure bending is studied by using finite element method (FEM). It is revealed in the case of infinite length that the moment of the elastoplastic cylindrical tube is controlled by flattening ratio of tube. Also, it is shown that the flattening ratio of tube can be expressed by axial and circumferential stress as a function of the material and geometrical properties and curvatures. Based on these facts, an approximate numerical method to estimate the maximum moment of cylindrical tubes is proposed, and its validity is shown by comparing with numerical results of FEM.
\end{abstract}

Key Words: Plasticity, Ovalisation, Pure Bending Collapse, Cylindrical Tube, Finite Element Method

\section{1. 緒言}

円筒の純曲げにおける断面の扁平現象は Brazier ${ }^{(1)}$ によって指摘されて以来, 多くの研究者によって検討 されている ${ }^{(1) \sim(6)}$.これによって, 円筒の純曲げの際 に生じる崩壊は, 軸方向の圧縮応力による座屈に誘起 されるものの他に，断面の扁平によって誘起されるも のもあることが明らかにされている. すなわち, 扁平 がなければ，曲げモーメントは曲げとともに上昇する が，扁平によって曲げモーメントの上昇に最大值が現 れ，その最大值が生じた後これまでに軸全長にわたっ て一様に分布していた曲げ変形は，ある一箇所に集中 し, 曲げモーメントは減少し始める.このような曲げ モーメントの最大值を予測するためには，曲げに伴う 扁平を定量的に把握する必要がある. 本研究では曲げ モーメントが減少し始めることを崩壊と定義する.

これまでにも極薄肉円筒の弾性曲げにおける扁平は 理論的に解析されている ${ }^{(1),(3)}$. しかし, 塑性降伏を伴 う円筒の塑性曲げにおける扁平現象は FEM のような 数值シミュレーション解析によって多く検討されてき たが，塑性降伏に伴い扁平がどのように変化するかな ど，扁平と塑性降伏の関係についての検討は少なく， 塑性を考慮した扁平の評価式の提案も少ない.

* 原稿受付 2007 年 7 月 30 日.

*1 正員, フェロー, 東京理科大学工学部機械工学科(《1628601 東京都新宿区神楽坂 1-3).

*2 正員, 東京理科大学大学院工学研究科.

*3 正員, 東京理科大学工学部機械工学科

E-mail : chend@rs.kagu.tus.ac.jp
一方，著者らは先に，アルミニウム合金材を用いて 円筒の準静的軸圧潰実験 ${ }^{(7)}$ を行い, 大変形による崩壊 挙動に関して試験結果と有限要素法解析による数值解 析結果とを比較し, 数値解析の有効性を確認している. また, Kyriakidesら ${ }^{(6)}$ はアルミニウム合金材を用いて 円筒の純曲げ実験を行い，これに対して，著者らは数 值解析によって Kyriakides ら ${ }^{(6)}$ の試験結果と同様の 結果が得られることを確認している.

そこで本研究では, FEMの数值解析結果を用いて, とくに塑性降伏後の扁平に着目して検討を行い，また その結果に基づいて，円筒の扁平に対する評価の近似 式を提案してみる。

\section{2. 解 析 方 法}

有限要素法汎用ソフトMSC.Marc を用い, 図 1 に示 す長さ $L$, 肉厚 $t$, 平均半径 $R$ の薄肉円筒の右端を剛体 板に固定する. 左端には Stephens $ら^{(2)}$, Guarracino ${ }^{(3)}$ と同様に，端部のめぐれを防ぐために，変形できない 蓋を設けるため, 肉厚 $5 t$ の蓋を設け, 蓋部分に $z$ 軸 回りの回転変位を与える. 円筒の材料は等方・均質な 弹塑性材料とし, 塑性降伏条件としてミーゼスの降伏 条件を用いて, 円筒の曲げに伴う塑性大変形解析を行 う. 塑性降伏後の応力-ひずみ関係は, 主に次式

$$
\sigma=\sigma_{Y}+E_{h}\left(\varepsilon-\frac{\sigma_{Y}}{E}\right)=\frac{E-E_{h}}{E} \sigma_{Y}+E_{h} \varepsilon
$$

で示すような，加工硬化係数 $E_{h}$ が一定な線形硬化則 を用いるが，提案する円筒扁平の評価式の有効性を示 
すために, 次式

$$
\sigma=\left[\frac{7}{3} \varepsilon E \sigma_{Y}^{(n-1)}-\frac{4}{3} \sigma_{Y}^{n}\right]^{\frac{1}{n}}
$$

で示すような, $n$ 乗の硬化則も用いる.ここに, $E$ は縦 弾性係数, $v$ はポアソン比, $\sigma_{Y}$ は降伏応力であり, 本 研究では, とくに断らない限り, $E=72.4 \mathrm{GPa}, v=0.3$ とする.

非線形挙動の定式化としてアップデーテッドラグ ランジュ法を用いて幾何学的非線形性を考慮し, 平衡 方程式を満たすための修正計算法としてニュートン・ ラプソン法を採用している，モデル化に際しては，曲 げ変形が滑らかに生じるように, 円周方向に 36 分割, 軸方向には，各分割要素がほぼ正方形となるように分 割して, 四辺形双一次厚肉シェル要素を用いて有限要 素離散化している.

また，円筒の扁平は両端の境界条件の影響も受け円 筒の長さによって異なる ${ }^{(3)}$ が, 本研究では, 両端の境 界条件の影響をほぼ受けないように，十分長い円筒を 用い，解析において半径 $R=25 \mathrm{~mm}$, 長さ $L=700 \mathrm{~mm}$ と固定寸る。

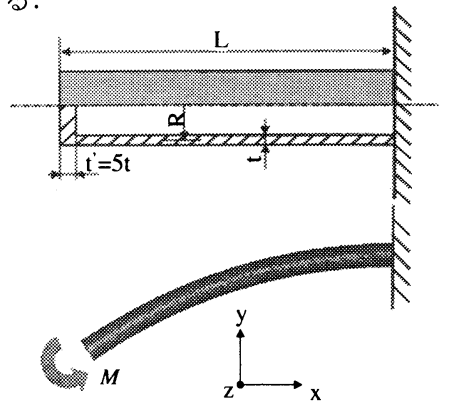

Fig. 1 Tube geometry and loading condition

\section{3. 解析結果および検討}

3.1 円筒の塑性曲げに伴う扁平の特幑

図 2 に, 肉厚 $t=0.5 \mathrm{~mm}$ の円筒について, 塑性降伏が生じない ように降伏応力 $\sigma_{y}$ を十分大きい值に設定して求めた, 最大曲げモーメントが生じるまでの，円筒断面の縦方 向半径の短縮 $R-b$ および横方向半径の広がり $a-R$ $(a$ と $b$ はそれぞれ，扁平に伴う円筒断面の横方向と 縦方向の半径である）と軸方向の曲率 $\kappa_{g}$ （中心軸の曲 率）の関係を示す．図には，比較のため円筒の弾性曲 げに対する Brazier ${ }^{(1)}$ の理論解析の結果も示している. 図からわかるように, 曲げ曲率 $\kappa_{g}$ が小さいときは両 者はよく一致し, 本研究の解析の有効性は確認される. なお， $\kappa_{g}$ がある程度大きくなると両者の差は現れる が，それはBrazierの理論解析において，円筒の扁平 に伴う変位などを十分小さい值としそれらの積などの
項を省略した近似手法によるものと考えられる．たと えば，図に示すように， $\kappa_{g}=0.3 \mathrm{~m}^{-1}$ のとき， $R-b$ ま たは $a-R$ は約 $4 \mathrm{~mm}$ であり，もしそれに対応する半 径方向の変位を無限小の值としてそれらの積などを省 略すると, $(4 / 25)^{2} \cong 3 \%$ オーダーの誤差が生じる可能 性があることは予想できる.

また，図 2 からわかるように，曲げ曲率 $\kappa_{g}$ が小さ いときは $R-b \cong a-R$ であるが， $\kappa_{g}$ の増加に伴い， $R-b>a-R$ となる. 以下，丹筒の扁平を表す指標と して $R-b$ を $R$ で除して無次元化した值 $1-b / K$ を用 いて検討を行う。

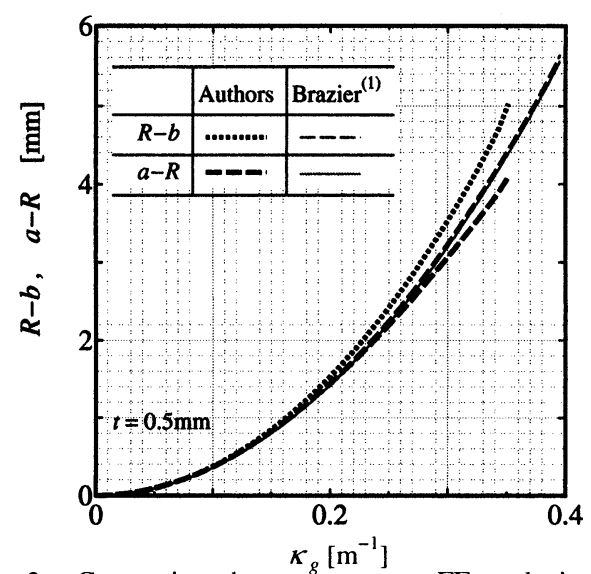

Fig. 2 Comparison between present FE analysis and Brazier's theory ${ }^{(1)}$ for elastic material

図 3 は 2 直線硬化則を用いて, 加工硬化倸数 $E_{h} / E=0.005,0.01,0.02$ の 3 種類の材料に対して, 肉 厚 $t=2 \mathrm{~mm}$ と降伏応力 $\sigma_{Y} / E=0.001$ を固定して, 扁 平 $1-b / R$ と無次元化曲率 $\kappa_{g} \times R^{2} / t$ との関係を示し たものである．図には比較のため, 同じ円筒の弾性曲 げ（塑性降伏が生じないように降伏态力を十分大きい 值に設定した場合をいう．以下同様）に伴う扁平曲線 (本研究では， $\kappa_{g}$ の増加に伴う $1-b / R$ の変化を扁平 曲線と呼ぶ）も示している. 図3からわかるように扁 平曲線に及ぼす加工硬化の影響は小さい，また，弾性 曲げは塑性曲げに比べて，同じ曲げ曲率による断面の 扁平が大きいことがわかる，例えば，図 3 に示した例 では， $\kappa_{g} \times R^{2} / t=0.2$ のとき塑性曲げでは $1-b / R \approx$ 0.01 に対して弾性曲げでは $1-b / R \approx 0.035$ である.

図 4 は 2 直線硬化則を用いて, 降伏応力 $\sigma_{Y} / E=0.00025,0.001,0.003,0.005$ の 4 種類の材 料に対して, 肉厚 $t=2 \mathrm{~mm}$ と加工硬化係数 $E_{h} / E=0.01$ を固定して求めた $1-b / R$ と $\kappa_{g} \times R^{2} / t$ の関係を示 したものである. 図4 からわかるように, 降伏応力 $\sigma_{y} / E$ が小さいほど, $\kappa_{g}$ の増加に伴う円筒断面扁平の 
進展が遅い，図 5 は 2 直線硬化則を用いて，円筒肉厚 $t=0.25,0.5,1,2 \mathrm{~mm}$ の 4 種類の厚さに対して降伏応力 $\sigma_{Y} / E=0.001$, 加工硬化係数 $E_{h} / E=0.01$ を固定して求 めた, $1-b / R$ と $\kappa_{g} \times R^{2} / t$ の関係を示したものであ る. 図 5 には比較のため, 肉厚 $t=0.5,2 \mathrm{~mm}$ の 2 種類 の円筒の弾性曲げによる扁平曲線も示している.この 図からわかるように, 弾性曲げの場合, 扁平 $1-b / R$ は無次元化曲率 $\kappa_{g} \times R^{2} / t$ のみの関数として整理でき るが, 塑性曲げの場合, $1-b / R$ と $\kappa_{g} \times R^{2} / t$ の関数 関係は肉厚さ $t$ によって異なり, 肉厚さ $t$ が厚いほど 同じ $\kappa_{g} \times R^{2} / t$ に対する $1-b / R$ の值は小さい.

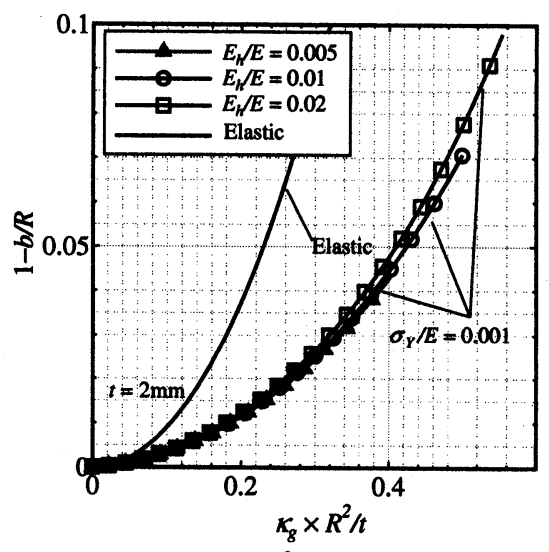

Fig. 3 Relation of $\kappa_{g} \times R^{2} / t$ and $1-b / R$ for three levels of hardening ratio $E_{h} / E$

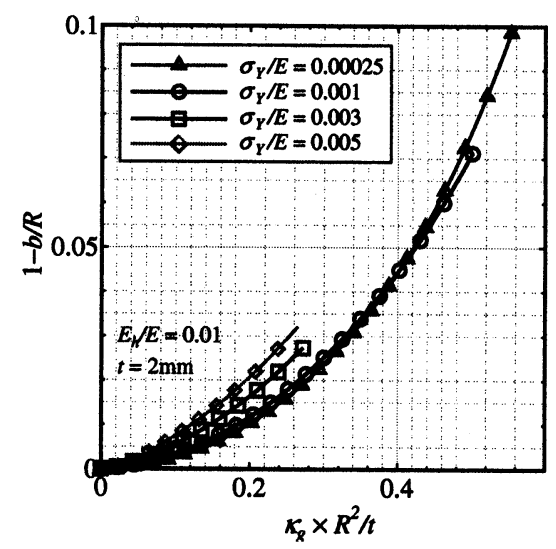

Fig. 4 Relation of $\kappa_{g} \times R^{2} / t$ and $1-b / R$ for four levels of yield stress ratio $\sigma_{Y} / E$

図 6 は, 図 3 に示した, $E_{h} / E=0.01$ の場合の扁平曲 線と弹性曲げの扁平曲線を両対数線図で再プロットし て示寸ものである. 図6からわかるように, 弾性の場 合の扁平は式

$$
1-\frac{b}{R} \approx\left(\frac{\kappa_{g} R^{2}}{t}\right)^{2}
$$

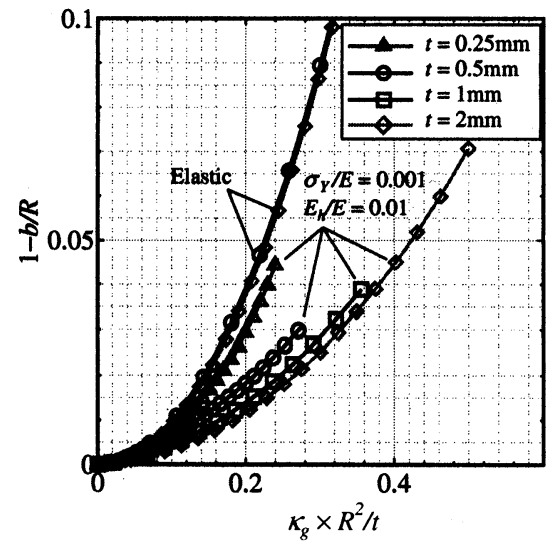

Fig. 5 Relation of $\kappa_{g} \times R^{2} / t$ and $1-b / R$ for four levels of thickness $t$

のように, 無次元化扁平量 $1-b / R$ は無次元化曲率 $\kappa_{g} \times R^{2} / t$ の 2 乗に比例する. これに対して, 塑性曲 げの場合, 図 6 に示したように, その扁平曲線の傾き は最初 2 であったが，その後一旦下がってから再び 2 に戻るように, $\left(\kappa_{g} \times R^{2} / t\right)$ の指数が曲げ変形とともに 変化する.

図 6 に示した, 曲げ変形とともに変化する曲線の $\left(\kappa_{g} \times R^{2} / t\right)$ の指数をより詳細に検討寸るために図 7 に, 図 6 に示した曲線の傾きを扁平速度指数 $v_{b}$ と称し,

$$
v_{b}=\frac{d\left[\log _{10}(1-b / R)\right]}{d\left[\log _{10}\left(\kappa_{g} R^{2} / t\right)\right]}
$$

扁平速度指数 $v_{b}$ を $\left(\kappa_{g} \times R^{2} / t\right)$ の関数として再プロッ トして示寸. 図 7 からわかるように, 扁平速度指数 $v_{b}$ からは曲げに伴う円筒の扁平の進展は基本的に 3 つの 特徴がある段階に分けられる. 段階 I では, 扁平速度 指数 $v_{b}$ が一定で, 約 2 であり，段階IIでは， $v_{b}$ が急激 に下がり，段階亚では $v_{b}$ が徐々に上昇し約 2 に戻る.

図7で示した段階における扁平と塑性降伏との関係 を見るために，まず，図中の段階 I，II の交点におけ る曲率 $\kappa_{g}$ を用いて, 式

$$
\sigma_{x}=E R \kappa_{g}
$$

で求めた，これらの曲率 $\kappa_{g}$ に対応する円筒の上頂点 の軸方向応力 $\sigma_{x}$ と材料の降伏応力 $\sigma_{Y}$ との比 $\sigma_{x} / \sigma_{Y}$ を表 1 の第 4 行に示す. 表 1 からわかるように，それ らの比はほぼ1である。したがって，段階 I では，塑 性降伏がまだ発生していないので, 扁平速度指数 $v_{b} か ゙$ 弾性曲げと同じ值の 2 となることがわかる. そして, 円筒上下頂点での塑性降伏が発生すると, 段階 I から IIへの遷移が起こり, 扁平速度指数 $v_{b}$ が小さくなる. 塑性降伏が発生すると, 扁平速度指数 $v_{b}$ が小さく なる理由は, 図 8 に示す, 扁平に関する力学モデルか 


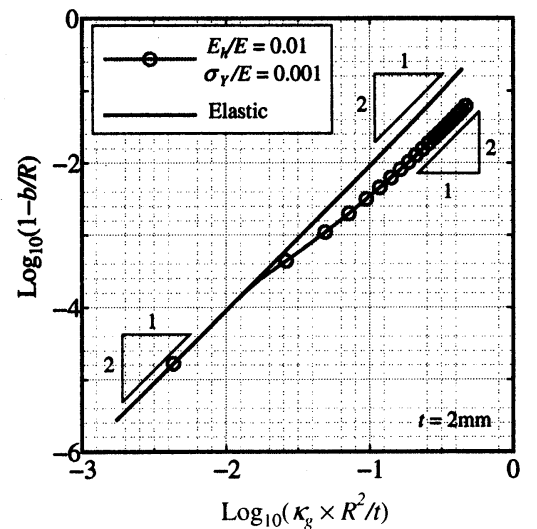

Fig. 6 Comparison between elastic and plastic bendings for flatteing

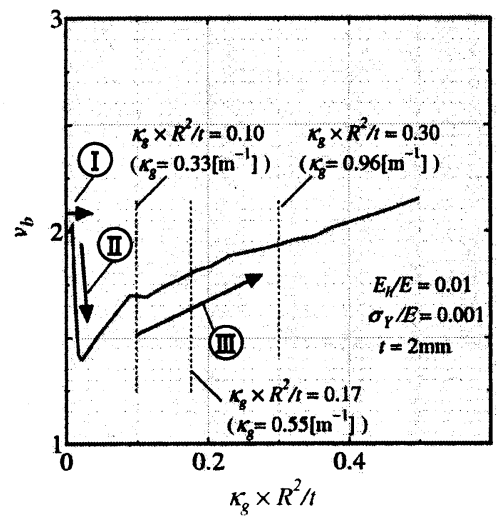

Fig. 7 Relation of $\kappa_{g} \times R^{2} / t$ and $v_{b}$ for plastic bending

Tablel:Result of numerical analyses

\begin{tabular}{|c|c|c|c|c|c|c|}
\hline & \multicolumn{5}{|c|}{$\sigma_{y} / E=0.001$} & \multirow{2}{*}{$\begin{array}{c}\begin{array}{c}\sigma_{r} / E \\
=0.003\end{array} \\
\begin{array}{c}E_{h} / E \\
=0.05\end{array}\end{array}$} \\
\hline & \multicolumn{3}{|c|}{$E_{h} / E=0.01$} & $\begin{array}{l}E_{k} / E \\
=0.05\end{array}$ & $n=5$ & \\
\hline & $\begin{aligned} & t / R \\
= & 1 / 25\end{aligned}$ & $\begin{array}{l}t / R \\
=2 / 25 \\
\end{array}$ & $\begin{aligned} & t / R \\
&= 3 / 25 \\
&\end{aligned}$ & $\begin{array}{c}1 / R \\
=2 / 25 \\
\end{array}$ & $\begin{array}{c}t / R \\
=2 / 25 \\
\end{array}$ & $\begin{aligned} & t / R \\
&= 2 / 25 \\
&\end{aligned}$ \\
\hline$\kappa_{g} R^{2} / t$ & 0.0263 & 0.0129 & 0.00845 & 0.0129 & 0.0136 & 0.0387 \\
\hline$\sigma_{x} / E$ & $1.05 \times 10^{-3}$ & $1.03 \times 10^{-3}$ & $1.01 \times 10^{-3}$ & $1.03 \times 10^{-3}$ & $1.08 \times 10^{-3}$ & $3.10 \times 10^{-3}$ \\
\hline$\sigma_{x} / \sigma_{Y}$ & 1.052 & 1.032 & 1.014 & 1.033 & 1.085 & 1.033 \\
\hline$\theta_{p}$ & $32^{\prime \prime}$ & $33^{\circ}$ & $33^{\circ}$ & 33 & $34^{\circ}$ & 34 \\
\hline$v_{b}$ & 1.39 & 1.40 & 1.41 & 1.43 & 1.54 & 1.43 \\
\hline$v_{b}^{*}$ & 1.90 & 1.94 & 1.95 & 2.05 & 1.88 & 2.04 \\
\hline
\end{tabular}

$v_{b}^{*}$ is $v_{b}$ for $\left.\sigma_{\theta}\right|_{\text {eq.(12) }} / \sigma_{Y}=3$

ら説明できる，図 8(a) は，曲げ曲率 $k_{g}$ のときの円筒 の一部分を示すものである. 図 8(a)に示すように, 幅 $d x=d \phi / k_{g}$ のリングの両端面に, 曲げによって垂直応 力 $\sigma_{x}$ が生じる. 応力 $\sigma_{x}$ は近似的に式

$$
\sigma_{x}= \begin{cases}E\left(\kappa_{g} R \sin \theta\right) & \kappa_{g} R \sin \theta<\sigma_{y} / E \\ \sigma_{y}+E_{h}\left(\kappa_{g} R \sin \theta-\frac{\sigma_{y}}{E}\right) & \kappa_{g} R \sin \theta>\sigma_{y} / E\end{cases}
$$

で評価できる．なお，ここの説明では，2 直線硬化則 に従う材料を用いる. 円筒の曲げによって，応力 $\sigma_{x}$ により半径方向の分布力が生じ, その密度 $q$ は

$$
q=\sigma_{x} t \kappa_{g}
$$

である、したがって，円筒の扁平は，図 8(b) に示すよ うな, 密度 $q$ の力による曲がりはりの変形問題として 検討できる.

このようなモデルからまず，弾性範囲において傾き が 2 であることが理解できる，すなわち弾性範囲では， この曲がりはりのたわみは荷重に比例するが，その荷 重密度 $q$ は次式

$$
q=E R t \sin \theta \kappa_{g}^{2}
$$

に示すように, 曲率 $\kappa_{\mathrm{g}}$ の 2 乗に比例するため, 扁平 は曲率 $\kappa_{g}$ の 2 乗に比例することとなる．そして，曲 げに伴い上端部付近で塑性降伏が生じると, その荷重 密度 $q$ は式

$$
q=\left[\sigma_{y}+E_{h}\left(\kappa_{g} R \sin \theta-\frac{\sigma_{y}}{E}\right)\right] t \kappa_{g}
$$

のようになり，その上昇率 $d q / d k_{g}$ は弾性の場合より 小さい. したがって, 円筒の上下頂点で塑性降伏が生 じると, 曲がりはりの中央部での分布荷重の上昇率が 小さくなるため, 曲げに伴うたわみの上昇率も弾性の 場合よりは小さくなり, 扁平速度指数 $v_{b}$ は 2 より小 さくなることとなる.
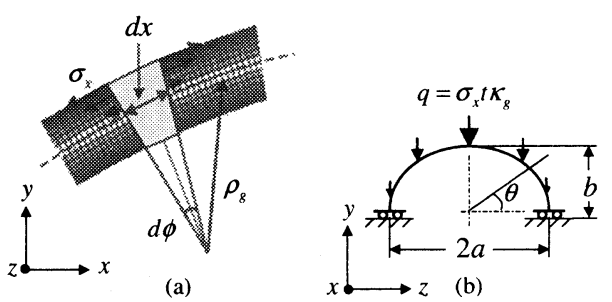

Fig. 8 Schematic representation of mechanical model for pure bending: (a) axial cross-section; (b) radial cross-section

図 9 は, いくつかの曲率 $\kappa_{g}$ (その中の $\kappa_{g} R^{2} / t=0.022$ は段階 II と III の交点に対応する曲率）に対応する各変 形段階での，円筒断面における塑性域の広がりを示 すものである.ここに，色の薄さは相当塑性ひずみの 大きさを示し，色が薄いほど相当塑性ひずみが大き いことを示す．また，弾性域との境界も破線で示して いる.ここでは，対称性を考え，断面の 4 分の 1 だ けを示寸. 図 9 からわかるように, 段階 $I\left(\kappa_{g} R^{2} / t=\right.$ $0.013,0.017,0.022 ） に お い て ，$ 曲げ曲率 $\kappa_{g}$ の増加に 伴い, 円筒の上下頂点に生じた塑性域は両側へと急速 


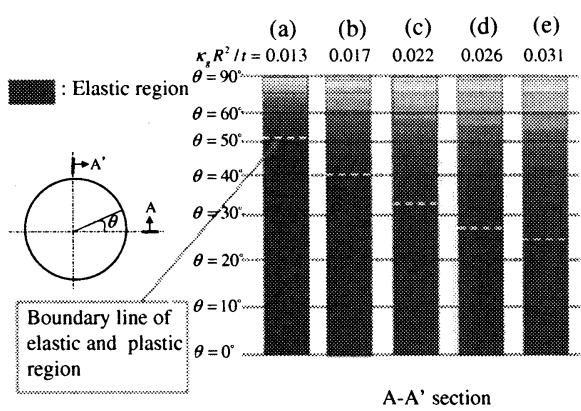

Fig. 9 Variation of plastic region on circumferential A-A' section at phase (a),(b),(c),(d) and (e) corresponding to $\kappa_{g} R^{2} / t=0.013,0.017,0.022$, 0.026 , and 0.031

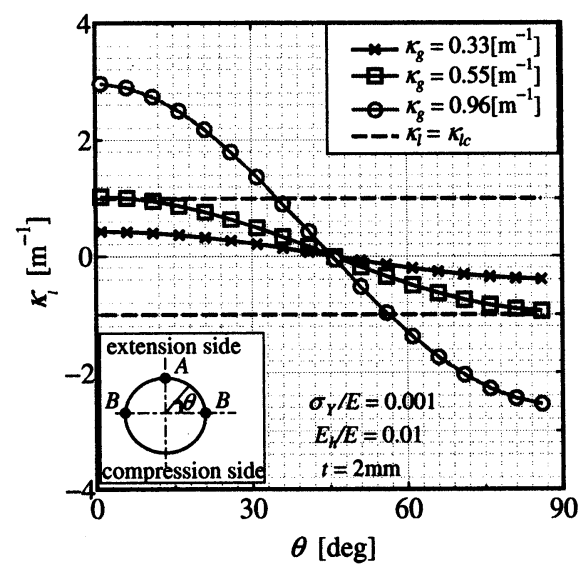

Fig. 10 Relation of $\theta$ and $\kappa_{l}$ for three levels of $\kappa_{g}$

に広がっていく，扁平速度指数 $v_{b}$ が最小となる曲率 $\kappa_{g} R^{2} / t=0.022$ において, 塑性域は図 9 の (c) で示し たように約 $\theta=30^{\circ}$ まで広がっている.

表 1 の第 5 行と 6 行にはそれぞれ, 扁平速度指数 $v_{b}$ が最小となる曲率 $\kappa_{g}$ における塑性域の広がり角度 $\theta_{p}$ およびそのときの扁平速度指数 $v_{b}$ を示している. 表 1 からわかるように, 扁平速度指数 $v_{b}$ が最小となる 曲率 $\kappa_{g}$ における塑性域の広がり角度 $\theta_{p}$ およびそのと きの扁平速度指数 $v_{b}$ の值は円筒の幾何寸法や材料性 質などによって変化するものの，おおよそ $\theta_{p} \approx 30^{\circ}$, $v_{b} \approx 1.5$ である.

また, 円筒の扁平に伴い周方向の曲げも生じる. 周 方向の曲げに伴うその曲率の変化を $\kappa_{l}$ とすると， $\kappa_{l}$ は式

$$
\kappa_{l}=\frac{1}{\rho_{l}}-\frac{1}{R}
$$

で評価される.ここに， $\rho_{l}$ は円筒の横断面各点での 曲率半径である。図 10 に, 図 7 で扱った円筒を例 として, 図 7 の $\kappa_{g} R^{2} / t=0.10,0.17,0.30$ (それぞれ $\kappa_{g}=0.33,0.55,0.96$ に対応する）のときの, 周方向に おける $\kappa_{l}$ の分布を示す. 図 10 からわかるように, 扁 平によって, $\theta=90^{\circ}$ の点 $\mathrm{A}$ と $\theta=0^{\circ}$ の点 $\mathrm{B}$ (図 10 を参照）に大きい周方向の曲げが生じる. 点 $\mathrm{B}$ におい て, 軸方向の曲げによる軸方向応力 $\sigma_{x}$ が常にゼロで, それによる塑性降伏は起こらないが， $\kappa_{l}$ が次式

$$
\left|\kappa_{l}\right|>\kappa_{l c}, \quad \kappa_{l c}=\frac{\sigma_{Y}}{E t / 2}
$$

のように $\kappa_{l c}=2 \sigma_{Y} / E t$ より大きければ, 円筒の両側 の点 $\mathrm{B}$ に, 外表面と内表面から塑性変形が発生する. 図 10 には $\kappa_{l c}$ の值を破線で示している. $\kappa_{l c}$ の值との 比較からわかるように, $\kappa_{g}=0.55$ のときに, 点 $\mathrm{B} の$ 円筒内外表面において塑性降伏が発生した. 軸方向の 曲げ曲率 $k_{g}$ がさらに大きくなり $\kappa_{g}=0.96$ のとき, 図 10 に示したように, 点 $\mathrm{B}$ における周方向の曲率 $\kappa_{l}$ は さらに大きくなるため, 塑性域はその内外表面から厚 さの中心へと広がる. また，このとき， $\left|\kappa_{l}\right|>\kappa_{l c}$ の $\theta$ も大きくなっている.

段階IIIにおいて，図 9 の (d), (e) で示したように, 軸方向応力 $\sigma_{x}$ による塑性域の周方向の広がりは段階 II のそれより遅くなる $\left(\left|d \theta_{p} / d k_{g}\right|_{\text {III }}<\left|d \theta_{p} / d k_{g}\right|_{\text {II }}\right)$. このことを反映して, 段階IIにおける扁平速度指数 $v_{b}$ は最小値から徐々に上昇する. そして， $k_{g}$ がさらに大 きくなり $\kappa_{g}=0.55$ のきから, 円筒の両側からも, 周 方向の曲げによる塑性域は発生した。これによって, $v_{b}$ はさらに大きくなる.ここで, 両側の点 $\mathrm{B}$ の曲率 $\kappa_{l B}$ を用いて次式

$$
\sigma_{\theta}=\frac{E t \kappa_{l B}}{2}
$$

を用いて応力 $\left.\sigma_{\theta}\right|_{\text {eq.(12) }}$ を求めた. 応力 $\left.\sigma_{\theta}\right|_{\text {eq.(12) }}$ は実 際の点 $\mathrm{B}$ の忘力ではないが, それと降伏応力との比 $\left.\sigma_{\theta}\right|_{\text {eq.(12) }} / \sigma_{Y}$ は, 曲率 $\kappa_{l}$ によって生じる両端での塑性 域の広がりに対応する 1 つの指標として用いることが できる. 表 1 の第 7 行に, その比の值が 3 となるとき の扁平速度指数 $v_{b}$ の值を示す. 表 1 からわかるよう に, $\left.\sigma_{\theta}\right|_{\text {eq.(12) }} / \sigma_{Y}=3$ のとき, 扁平速度指数 $v_{b}$ はほぼ 2 となっている.

以上に述べた, 円筒の塑性曲げにおける横断面扁平 の特徵をまとめると,

（1）塑性降伏が生じるまで, 扁平速度指数 $v_{b}$ は弾性 曲げの場合と同じで約 2 である.

(2) 軸方向の曲げ応力 $\sigma_{x}$ によって円筒の上下部に塑 性域が発生し, その塑性域は曲げの進展に伴い急 速に上下端から両側へと広がる.

（3）上下部で塑性降伏が生じると, 扁平速度指数 $v_{b}$ は急速に約 1.5 まで下がる，そのときの塑性域の 広がりは約 $\theta \approx 30^{\circ}$ である. 
(4) その後, 扁平速度指数 $v_{b}$ は徐々に上昇する. とくに, 忘力 $\left.\sigma_{\theta}\right|_{\text {eq.(12) }}$ と降伏応力 $\sigma_{Y}$ との比 $\left.\sigma_{\theta}\right|_{e q .(12)} / \sigma_{Y}$ の值が 3 となるとき扁平速度指数 $v_{b}$ は約 2 に戻る.

3.2 扁平曲線の近似式 以上の検討に基づいて, 円筒の扁平に関する近似式を求める。 まず，図 11 の ように, (a) 変形段階 I に対して扁平速度指数 $v_{b}=2$ の水平の直線で近似し, (b) 段階Iに対して, その過 程が短いということから， $x=x_{1}$ の真直ぐの線分で近 似し，またその線分における扁平速度指数 $v_{b}$ の最小 值は，表 1 より 1.5 とする. また，(c) 段階而に対し てはそれを斜めの直線と近似するが, 扁平速度指数 $v_{b}$ の值が再び 2 に戻るのは, $\left.\sigma_{\theta}\right|_{\text {eq.(12) }} / \sigma_{Y}=3$ のときで あると仮定する. さらに, (d) 扁平速度指数 $v_{b}$ の值が 2 に戻ったら, その後扁平速度指数 $v_{b}=2$ の水平の直 線で近似する. 寸なわち, 円筒の扁平速度について次 式のように場合分けして考える.

$$
v_{b}=\left\{\begin{array}{lll}
2 & \text { for } & x \leq x_{1} \\
d_{1} x+d_{2} & \text { for } & x_{1} \leq x \leq x_{2} \\
2 & \text { for } & x \geq x_{2}
\end{array}\right.
$$

$こ こ に$

$$
x=\kappa_{g} R^{2} / t
$$

また， $x_{1}$ は円筒上下部での塑性降伏の発生に対応し，

$$
x_{1}=\frac{\sigma_{Y} R}{E t}
$$

式 (13) に基づけば, 円筒の扁平は次式

$$
1-\frac{b}{R}= \begin{cases}C_{1} x^{2} & \text { for } x \leq x_{1} \\ C_{2} x^{d_{2}} e^{d_{1} x} & \text { for } x_{1} \leq x \leq x_{2} \\ C_{3} x^{2} & \text { for } x \geq x_{2}\end{cases}
$$

のように，近似的に評価される.

弾性曲げの FEM の解析結果および式 (3) から, 式 (16) の中の未知係数 $C_{1}=1.0$ と定め, そしてその他の 末知数 $x_{2}, C_{2}, C_{3}, d_{1}$ および $d_{2}$ などは以下の 5 つの条件 から定める.

(1) $x_{1}$ での連続条件より

$$
x_{1}^{2}=C_{2} x_{1}^{d_{2}} e^{d_{1} x_{1}}
$$

（2）表 1 より, $x=x_{1}$ のときの $v_{b}$ の最小值が 1.5 であ るため,

$$
d_{1} x_{1}+d_{2} \cong 1.5
$$

(3) $x=x_{2}$ のとき $v_{b}$ の值が 2 であるため,

$$
d_{1} x_{2}+d_{2} \cong 2.0
$$

(4) また $x=x_{2}$ のとき, $\left.\sigma_{\theta}\right|_{\text {eq.(12) }} / \sigma_{Y}=3$ であるため,

$$
\frac{t}{2}\left(\frac{1}{\rho_{l}}-\frac{1}{R}\right) \cong 3 \frac{\sigma_{Y}}{E}
$$

ここに，両側での周方向の曲率半径 $\rho_{l}$ は断面を 楕円と仮定することで, 次式で示すように短半径 $b$ で表すことができる.

$$
\frac{1}{\rho_{l}}=\frac{2 R-b}{b^{2}}
$$

(5) $x_{2}$ での連続条件より

$$
C_{3} x_{2}^{2}=C_{2} x_{2}^{d_{2}} e^{d_{1} x_{2}}
$$

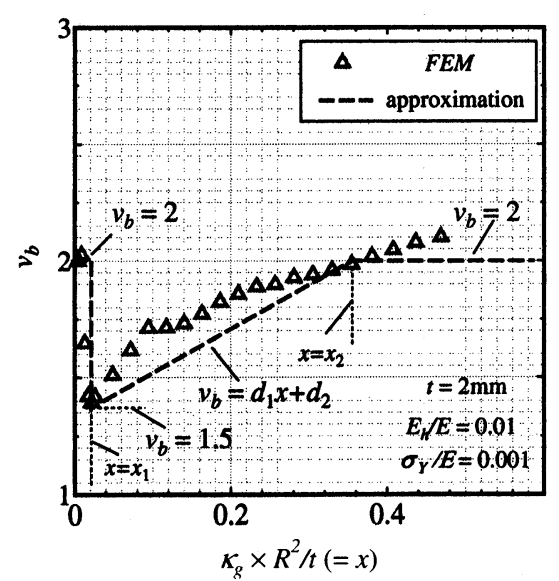

Fig. 11 Poly-linear approximation for relation of $v_{b}$ $\kappa_{g} R^{2} / t$

式 (17)〜(20) および式 (22)より, 未知数 $x_{2}, C_{2}, C_{3}, d_{1}$ および $d_{2}$ などを定めれば, 扁平曲線の近似式を得る ことができる.ここで種々の場合について, 近似式 (16)による結果と FEM の結果との比較を行いその有 効性を示寸. 図 12 は, 図 3 に示した, 加工硬化係数 $E_{h} / E=0.005,0.01,0.02$ の 3 種類の 2 直線硬化則に従 う材料に対して FEM で求めた扁平曲線と, 近似式 (16) による予測值とを比較したものである. また, 図 13 は $n=5$ の $n$ 乗硬化則を用いて, 降伏応力 $\sigma_{y} / E=0.00025$, $0.001,0.003$ の 3 種類の材料について, $t=0.5 \mathrm{~mm}$ の円 筒に対して FEM で求めた扁平曲線と, 近似式(16)に よる結果とを比較したものである. 図 14 は $n=5$ の $n$ 乗硬化則を用いて, 円筒肉厚 $t=0.5,1,2 \mathrm{~mm}$ の 3 種類 の厚さについて, 降伏応力 $\sigma_{y} / E=0.001$ の円筒に対し て FEM で求めた扁平曲線と, 近似式 (16)による結果 とを比較したものである.これらの図からわかるよう に, 種々の場合に対応した精度の良い近似曲線が得ら れる.

3.3 曲げモーメント 求めた扁平の近似式を用 いることで, 曲げに伴うモーメント $M_{g}$ の変化を予測 することができる．扁平した円筒の断面を楕円と仮定 すれば, モーメント $M_{g}$ は式 


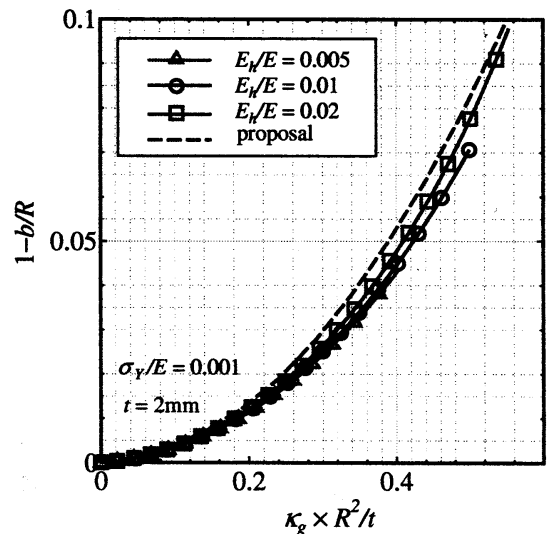

Fig. 12 Comparison between results of FEM and proposal method for three levels of hardening ratio $E_{h} / E$

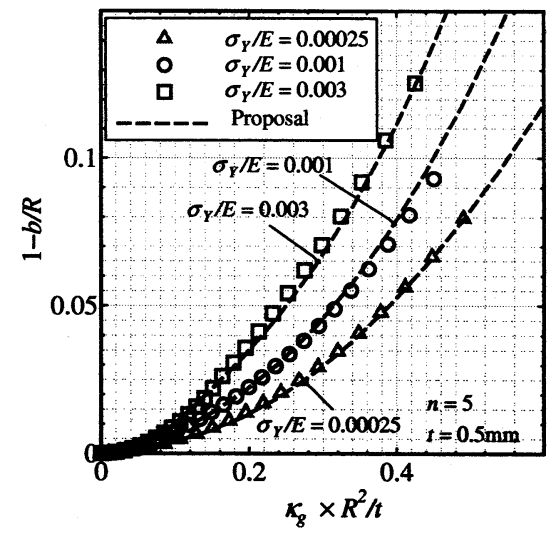

Fig. 13 Comparison between results of FEM and proposal method for three levels of yield stress $\sigma_{Y} / E$

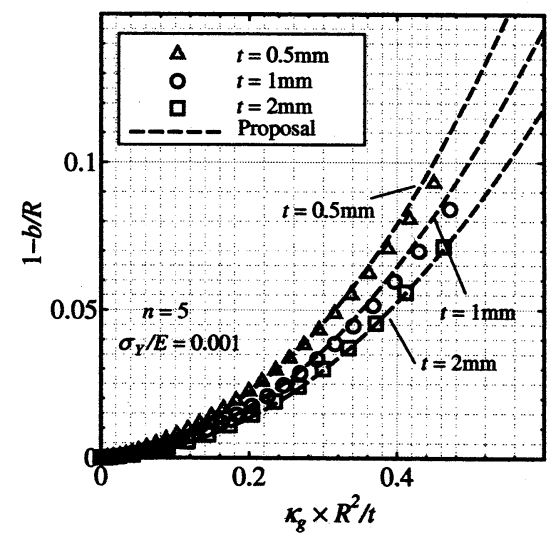

Fig. 14 Comparison between results of FEM and proposal method for three levels of thickness $t$

$$
M=4 t \int_{0}^{\pi / 2} \sigma_{x} b \sin \theta \sqrt{a^{2} \sin ^{2} \theta+b^{2} \cos ^{2} \theta} d \theta
$$

で求まる.ここに, 軸方向応力 $\sigma_{x}$ は式 (6) で評価さ れる。

図 15 はこのような近似手法で求めたモーメント $M g$ を破線で示し，FEMの結果との比較を示すものであ る. 図 15 からわかるように近似手法で求めたモーメ ント $M_{g}$ はFEM の結果とほぼ一致するが，曲率 $\kappa_{g}$ が 大きくなるにつれて誤差が大きくなる.

図 15 に示した誤差の原因を検討するために，図 16 に $\kappa_{g}=1.51\left[\mathrm{~m}^{-1}\right]$ のときの $\theta=30^{\circ}, 60^{\circ}, 90^{\circ}$ における 厚さ方向の忘力 $\sigma_{x}$ の分布について, FEM で求めた結 果と式 (6) で求めた值 (細い実線) との比較を示す。こ の図からわかるように，厚さ方向の応力 $\sigma_{x}$ の分布は 一様ではないため両者の值は一致しない。このことに 対して本研究では以下のように検討を行う.

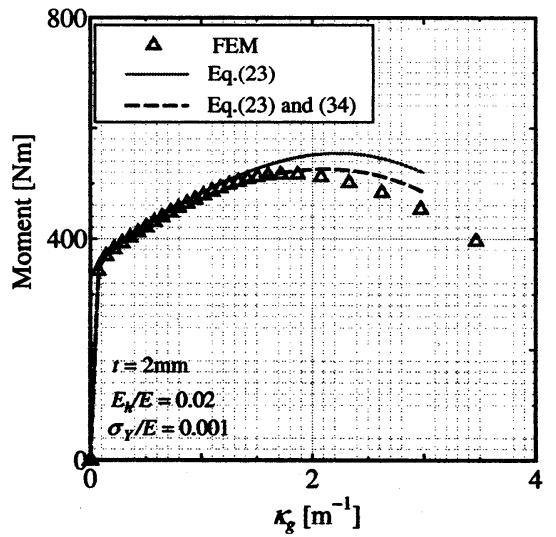

Fig. 15 Comparison between results of FEM and proposal method for moment- $\kappa_{g}$ relation

円筒曲げにおける応力とひずみの関係は，ひずみ増 分理論に基づき, Ruessの方程式

$$
\frac{\dot{e}_{x}}{\sigma_{x}^{\prime}}=\frac{\dot{e}_{\theta}}{\sigma_{\theta}^{\prime}}=\dot{\lambda}
$$

を用いて検討することができる。ここに， $\sigma_{x}^{\prime} ， \sigma_{\theta}^{\prime}$ は 偏差応力, $\dot{e}_{x}, \dot{e}_{\theta}$ は偏差ひずみ速度であり, また比例 定数交は

$$
\dot{\lambda}=\frac{3}{2} \frac{\dot{\bar{e}}}{\bar{\sigma}}
$$

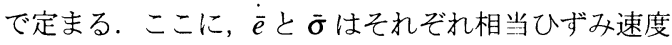
と相当応力である.

$$
\dot{\bar{e}}=\sqrt{\frac{2}{3}} \sqrt{\dot{e}_{x}^{2}+\dot{e}_{\theta}^{2}+\dot{e}_{z}^{2}}, \quad \bar{\sigma}=\sqrt{\frac{3}{2}} \sqrt{\sigma_{x}^{\prime 2}+\sigma_{\theta}^{\prime 2}+\sigma_{z}^{\prime 2}}
$$

薄肉円筒では， $\sigma_{z}=0$ であるため, 


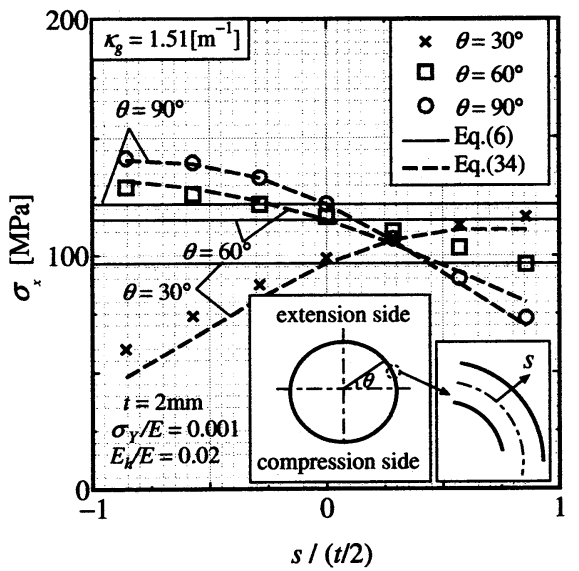

Fig. 16 Comparison between results of FEM and Eqs.(6),(34) for axial stress distribution

$$
\sigma_{x}^{\prime}=\frac{2 \sigma_{x}-\sigma_{\theta}}{3}, \quad \sigma_{\theta}^{\prime}=\frac{2 \sigma_{\theta}-\sigma_{x}}{3}
$$

となる.よって，

$$
\sigma_{x}=\frac{2 \bar{\sigma}}{3 \dot{\bar{e}}}\left(2 \dot{e}_{x}+\dot{e}_{\theta}\right), \quad \sigma_{\theta}=\frac{2 \bar{\sigma}}{3 \dot{\bar{e}}}\left(2 \dot{e}_{\theta}+\dot{e}_{x}\right)
$$

周方向のひずみを

$$
\dot{e}_{\theta}=\dot{e}_{\theta m}+\Delta \dot{e}_{\theta}
$$

として, 周方向の平均応力は

$$
\sigma_{\theta m}=0
$$

であることを考慮すれば，式 (28) の第 2 個目の式より

$$
\dot{e}_{\theta m}=-\frac{1}{2} \dot{e}_{x}
$$

と得られる。これを式 (28) の第 1 個目の式に代入す れば,

$$
\sigma_{x}=\frac{2 \bar{\sigma}}{3 \dot{\bar{e}}}\left(\frac{3}{2} \dot{e}_{x}\right)+\frac{2 \bar{\sigma}}{3 \dot{\bar{e}}} \Delta \dot{e}_{\theta}
$$

$こ こ に$

$$
\bar{e}^{2}=\dot{e}_{x}^{2}+\frac{4}{3} \Delta \dot{e}_{\theta}^{2}
$$

よって

$$
\sigma_{x}=\bar{\sigma} \frac{\dot{e}_{x}}{\dot{\bar{e}}}+\bar{\sigma} \frac{2 \Delta \dot{e}_{\theta}}{3 \dot{\bar{e}}}
$$

$こ こ に$

$$
\dot{e}_{x}=y \dot{\kappa}_{g}, \quad \Delta \dot{e}_{\theta}=s \dot{\kappa}_{l}
$$

図 16 に式 (34) で求めた断面における応力 $\sigma_{x}$ の分 布を破線で示す. 図からわかるように，式(34)を用い て求めた応力分布はFEM の結果と良く一致している. 図 15 に, 式 (34) で求めた応力 $\sigma_{x}$ を式 (23) に代入し て求めたモーメント $M_{g}$ の予測值を実線で示す. 図か らわかるようにその值と FEM の值には良い一致が見 られる。

\section{4. 結言}

本研究では, 有限要素法 (FEM) による弾塑性数值 解析を行い，円筒の曲げ崩壊に関する検討を行った. その結果，以下の点が明らかになった.

(1) 無限長の場合, 円筒の純曲げにおいて, 曲げ崩壊 を支配しているものは扁平である.

(2) 弾性曲げの場合, 扁平速度指数は $v_{b} \cong 2$ である が，塑性曲げの場合，円筒の上下端部から広がる 塑性域の生成により $v_{b}$ は急激に小さくなる.し かし, 軸方向応力 $\sigma_{x}$ による塑性域は $\theta \cong 30^{\circ} \sigma$ ところまで広がると $v_{b}$ は回復し，とくにその後， 円筒の両側に扁平による塑性域が生じると $v_{b}$ は さらに上昇し約 2 に戻る.

(3) (2) で述べた塑性降伏と $v_{b}$ の関係は3つの段階に 分けることで精度の良い近似曲線が得られる。

(4) 提案した扁平曲線, 肉厚さ方向の応力分布によっ て最大モーメント $M_{\max }$ を予測することが可能で ある。

\section{文献}

(1) Brazier, L. G., On the flexure of thin cylindrical shells and other "Thin" sections, Proceedings of the Royal Society of London, Series A, Vol.116(1927), pp.104-114.

(2) Stephens, W. B. et al., Collapse of long cylindrical shells under combined bending and pressure loads, American Institute of Aeronautics and Astronautics Journal, Vol.13, (1975), pp.20-25.

(3) Guarracino, F., On the analysis of cylindrical tubes under flexure: theoretical formulations, experimental data and finite element analyses, Thin-Walled Structures, Vol.41, (2003), pp.127-147.

(4) Gellin, S., The plastic buckling of long cylindrical shells under pure bending, International Journal of Solids and Structures, Vol.16, (1980), pp.397-407.

(5) Wierzbicki, T. and Sinmao, M. V., A simplified model of Brazier effect in plastic bending of cylindrical tubes, International Journal of Pressure Vessels and Piping, Vol.71, (1997), pp.19-28.

(6) Kyriakides, S. and Ju G. T., Bifurcation and localization instabilities in cylindrical shells under bending- I, II . Experiments,Predictions International Journal of Solids and Structures, Vol.29, (1992), pp.1117-1171.

(7) Haruyama, S., Ushijima, K. and Chen, D., Study of crack initiation in circular tubes of aluminum alloy under axially compressive load, The Japanese Society for Experimental Mechanics, Vol.3 (2003), pp.343-344. 